\title{
PEMERTAHANAN KEKHASAN PENGAJARAN KITAB KUNING PADA PONDOK PESANTREN DARUSSALAM MARTAPURA KALIMANTAN SELATAN (Telaah Aspek Linguistik dan Sosiolingustik)
}

\author{
Noorazmah Hidayati \\ STAI Rakha Amuntai, Kalimantan Selatan \\ Jl. Rakha, Pakapuran, Amuntai, Kalimantan Selatan \\ E-mail: noorazmahhidayati@gmail.com
}

\begin{abstract}
The Maintenance of the Unique Teaching of the Yellow Book At Pondok Pesantren Darussalam Martapura South Kalimantan (Review Linguistic and Sociolingustic Aspects). Pesantren as an Islamic educational institution has various characteristics. One of them is the uniqueness in teaching of yellow book, as applied in Pondok Pesantren Darussalam (PPD) Martapura. To achieve the purpose of pesantren tafaqquh fî ad-dîn, the yellow book must be mastered by santri. To master the yellow book, the element and the knowledge of yellow book are considered as the main tool. The emphasis on these two aspects also has an impact on the application of characteristic translations. The translation seems unique, rigid, and clumsy so that it is potentially difficult to understand and can even lead to misunderstandings. However, the specificity of teaching is instead maintained and can be accepted in the pesantren. This paper is intended to express how and why the specificity of yellow book teaching can survive and be maintained in PPD Martapura in terms of linguistic and sociolinguistic aspects.
\end{abstract}

Keywords: pesantren; yellow book; linguistic; sociolinguistic.

\begin{abstract}
Abstrak: Pemertahanan Kekhasan Pengajaran Kitab Kuning Pada Pondok Pesantren Darussalam Martapura Kalimantan Selatan (Telaah Aspek Linguistik dan Sosiolingustik). Pesantren sebagai lembaga pendidikan Islam memiliki karakteristik yang begitu beragam. Salah satunya adalah keunikan dalam pengajaran kitab kuning, seperti yang berlaku di Pondok Pesantren Darussalam (PPD) Martapura. Agar tujuan pesantren tafaqquh fî ad-dîn dapat dicapai, kitab kuning harus dikuasai oleh santri. Untuk mengusai kitab kuning unsur ilmu alat dan mufradât dianggap sebagai alat utamanya. Penekanan pada kedua aspek tersebut berdampak pula pada diterapkannya terjemahan berkarakteristik khas. Terjemahan tersebut tampak unik, kaku, dan janggal sehingga berpotensi sulit dipahami dan bahkan dapat menimbulkan kekeliruan pemahaman. Namun, kekhasan pengajaran tersebut justru tetap dipertahankan dan dapat diterima di kalangan pesantren. Tulisan ini ditujukan untuk mengungkapkan bagaimana dan mengapa kekhasan pengajaran kitab kuning dapat bertahan dan tetap dipertahankan di PPD Martapura ditinjau dari aspek linguistik dan sosiolinguistik.
\end{abstract}

Kata kunci: pesantren; kitab kuning; linguistik; sosiolinguistik.

\section{Pendahuluan}

Keberadaan pesantren sebagai lembaga pendidikan Islam telah diakui secara formal dan menjadi bagian integral sebagai subsistem dari sistem pendidikan nasional. Hal tersebut diatur secara khusus dalam UU No. 20 Tahun 2003 tentang Sistem Pendidikan Nasional yang menyatakan bahwa pesantren merupakan lembaga pendidikan keagamaan yang berfungsi mempersiapkan peserta didik menjadi anggota masyarakat yang memahami dan mengamalkan nilai-nilai ajaran agama. ${ }^{1}$

Lihat A. Fatah Yasin, Dimensi-dimensi Pendidikan Islam, (Malang: UIN-Malang Press, 2008), h. 254.
Dalam menjalankan fungsinya, pesantren sangat menekankan urgensi mempelajari ilmu agama Islam (tafaqquh fî ad-dîn) sebagaimana dinyatakan oleh Dhofier bahwa pendidikan pesantren bertujuan "meninggikan moral, melatih dan mempertinggi semangat, menghargai nilainilai spiritual dan kemanusiaan, mengajarkan sikap dan tingkah laku yang jujur dan bermoral, dan menyiapkan para murid untuk hidup sederhana dan bersih hati." "2 Untuk mencapai tujuan ter-

2 Zamakhsyari Dhofier, Tradisi Pesantren: Studi Tentang Pandangan Hidup Kiai, (Jakarta: LP3ES, 1982), h. 2. Lihat juga Faiqoh, "Pengajaran Kitab Kuning di Pondok Pesantren Cidahu Pandeglang”, Mimbar 28, No. 2 (2012), h. 219-227. 
sebut, kurikulum pesantren terfokus pada ilmu agama yang literaturnya memakai kitab-kitab klasik atau kitab kuning. Karenanya, pesantren berperan sebagai pusat transmisi ilmu-ilmu keislaman, terlebih kajian-kajian klasik. Dalam hal ini, kitab kuning telah menjadi karakteristik khas pesantren. ${ }^{3}$ Bahkan, melalui pengajaran kitab kuning, pesantren menjadi prasarana utama kiai untuk mentransmisikan corak pemikiran Islam tradisional (ahlu as-sunnah wa aljamâ'ah) di lingkungan pesantren dan masyarakat pada umumnya. ${ }^{4}$

Pondok Pesantren Darussalam (selanjutnya disingkat PPD) Martapura sebagai pesantren tertua di Kalimantan Selatan seiring dengan perkembangannya menyelenggarakan pendidkan kepesantrenan dan pendidikan formal. Jenis pesantren ini jika dilihat dari aspek penyelenggaran pendidikan termasuk sebagai pesantren kombinasi. ${ }^{5}$ Dalam hal ini, meskipun PPD Martapura bukan pesantren salafiyah dan telah banyak bersentuhan dan mengadopsi modernitas dalam pendidikan, PPD Martapura dikenal memiliki ciri khas yakni pengajaran kitab kuning.

Dalam pengajaran kitab kuning pada PPD Martapura terlihat keunikan di dalamnya, seperti guru cenderung menggunakan terjemahan berkarakteristik khas dengan menyertakan kata penanda untuk menegaskan kedudukan kalimah dalam jumlah karena unsur ilmu alat dan mufradât sangat diutamakan. Hal itu dapat dilihat pada kutipan materi al-Matn al-Ajrumiyah yang diajarkan berikut:

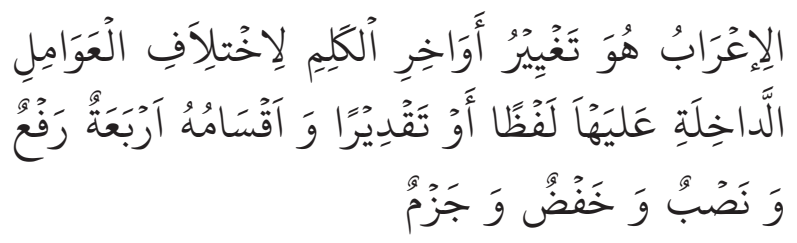

Bermula i'rab itu yaitu berubah-ubah sekalian akhir kalimah-kalimah karena bersalahan-bersalahan amil-

3 Yasmadi, Modernisasi Pesantren: Kritik Nurcholis Madjid terhadap Pendidikan Islam Tradisional, (Jakarta: Ciputat Press, 2002), h. 67.

${ }^{4}$ Lihat Martin van Bruinessen, Kitab Kuning, Pesantren dan Tarekat, edisi revisi. terj. Farid Wajidi, et. al, (Yogyakarta: Gading Publishing, 2012), h. 85 dan Zamakhsyari Dhofier, Tradisi Pesantren: Studi Tentang Pandangan Hidup Kiai, (Jakarta: LP3ES, 1982), h. 148.

${ }^{5}$ Lihat Yasmadi, Modernisasi Pesantren: Kritik Nurcholis Madjid terhadap Pendidikan Islam Tradisional (Jakarta: Ciputat Press, 2002), h. 71. amil yang masuk atasnya pada lafaz atau takdirnya dan bermula bahagian i'rab itu empat pertama baris di hadapan dan kedua baris di atas dan ketiga baris di bawah dan keempat jazam yakni mati. ${ }^{6}$

Berdasarkan kutipan di atas tampak terjemahan menganut kaidah bahasa Arab karena struktur kata dalam kalimat terjemahan sama persis dengan susunan kalimat aslinya. Terjemahan tersebut tidak menyesuaikan dengan kaidah bahasa Indonesia, melainkan mengikuti pada kaidah bahasa aslinya. Di antara yang tampak adalah digunakannya kata bermula di awal kalimat untuk menandakan kedudukan kata tersebut sebagai subyek atau mubtada'. Selain itu, kata sambung antarkata dalam kalimat g yang berarti "dan" digunakan secara berturut-turut, tidak terdapat pengganti "dan" seperti tanda baca koma, maupun kata serta.

Karena sangat mengutamakan unsur tarkib ilmu nahwu atau ilmu alat dan mufradât, terjemahan menjadi tampak unik, kaku, dan janggal, sehingga berpotensi sulit dipahami. Meskipun demikian, guru di PPD Martapura cenderung tetap menerapkan dan mempertahankan kekhasan pengajaran kitab kuning tersebut dan dapat dikatakan mampu menghasilkan lulusan yang kemudian menjadi ahli ilmu agama atau ulama berpengaruh di masyarakat. Permasalahan yang hadir dari fenomena itu adalah jika pemahaman terhadap materi kitab kuning cenderung sulit dilakukan dengan terjemahan yang khas maka patut dipertanyakan apakah pemahaman santri terhadap materi menjadi terabaikan karena guru tampak menekankan pada penguasaan ilmu nahwu, dan mengapa terjemahan tersebut tetap diterapkan dalam pengajaran kitab kuning pada PPD Martapura.

Fenomena unik di atas dianggap menjadi hal yang patut untuk ditelaah mengingat PPD Martapura sebagai pesantren tertua di Kalimantan Selatan tentu telah menghasilkan banyak lulusan. Alumni tersebut kemudian berpotensi menjadi penerus keberlanjutan kekhasan pengajaran PPD Martapurapa da pesantren yang didirikannya atau pada lembaga pendidikan tempat ia mengajar. Oleh karena itu, penting untuk diketahui bagaimana dan mengapa kekhasan pengajaran kitab

${ }^{6}$ Abu Abdillah Muhammad bin Daud as-Shanhaj bin al-Jurum, al-Matn al-Ajrumiyyah, (Surabaya: Bongkol Indah, t.th), h.3. 
kuning pada PPD Martapura cenderung tetap dipertahankan.

Karena pesantren merupakan lembaga pendidikan Islam yang berperan sebagai pusat transmisi ilmu-ilmu keislaman, pengajaran kitab kuning untuk tafaqquh fî ad-dîn menjadi karakteristik dan jati diri pesantren7. Oleh karena itu, fungsi utama pesantren adalah melahirkan muslim yang menguasai ilmu-ilmu agama Islam dan mengamalkannya, sehingga pengajaran kitab kuning merupakan hal yang dianggap urgen untuk dilaksanakan.

Kitab-kitab referensi yang diajarkan di pesantren bersumber dari kitab-kitab klasik yang ditulis oleh ulama abad pertengahan. Kitab kuning tersebut mengandung tata nilai yang termaktub dalam paham ahlu as-sunnah wa al-jamâ'ah, yakni jika dilihat dari aspek fikih, mengacu pada paham imam empat mazhab, sedangkan jika dilihat dari aspek akidah menganut paham imam Asy'ari, dan akhlak mengikuti paham imam Ghazali. Kitab-kitab tersebut dimuat ke dalam beberapa mata pelajaran.

Untuk menguasai kitab kuning, ilmu nahwu dan mufradât dianggap sebagai alat utama yang harus dikuasai. Karena menekankan pada aspek penguasaan qawaid dan mufradât, terjemahan yang digunakan mengutamakan struktur bahasa sumber, bukan bahasa sasaran, sehingga terjemahan menjadi terkesan kaku dan janggal. Penerapan dan pemertahanan terjemahan berkarakteristik khas dalam pengajaran kitab kuning ini tentu memiliki argumen ilmiah yang menarik untuk ditelisik lebih mendalam melalui kajian linguistik dan sosiolinguistik.

\section{Metodologi}

Penelitian ini merupakan penelitian kualitatif yang dilakukan secara natural di lapangan. Sumber data adalah pengajar, santriwati, dan pimpinan pesantren. Objek penelitian adalah karaktersitik khas pengajaran kitab kuning pada PPD Martapura. Teknik pengumpulan data menggunakan observasi langsung dan partisipan, wawancara semi terstruktur, dan dokumenter.

7 Mazro’atus Sa'adah, “Pengaruh Doktrin Tertutupnya Pintu ljtihad Terhadap Pola Pengajaran Hukum Islam di Pondok Pesantren Tradisional”, Jurnal At-Tajdid, Vol 1, No.1 (2012), h. 10
Teknik analisis data menggunakan reduksi, display, dan verifikasi data. Teknik pemeriksaan data menggunakan trianggulasi sumber dan teknik.

\section{Hasil dan pembahasan}

PPD Martapura berdiri pada 14 Juli 1914 yang pada waktu itu benama Madrasah Darussalam atau dikenal pula dengan nama Madrasah Islam Darussalam. Lembaga pendididkan Islam tersebut didirikan oleh $\mathrm{H}$. Jamaluddin dengan dibantu oleh beberapa rekan beliau, yaitu K.H. M. Tamrin, K.H. Ibrahim Kadir, K.H. Hasan Gampal, K.H. Hasan, K.H. Abdurrahman, dan K.H. M. Ali di Kota Martapura. ${ }^{8}$

Pada awal berdirinya, pesantren Darussalam tampil dengan sistem pengajaran tradisional. Materi-materi yang diajarkan terbatas hanya di bidang keagamaan. Kegiatan pengajaran dilakukan dengan cara halaqah, yakni para murid duduk bersimpuh mengelilingi guru sambil mendengarkan materi keagamaan yang diberikan. Pendidikan dan pengajaran semacam ini tidak mengenal kelas atau batasan umur; anak-anak dan orang dewasa bercampur menjadi satu kelompok dengan tanpa ada evaluasi belajar. Perkembangan PPD Martapura mengalami lompatan besar ketika pesantren dipimpin $\mathrm{KH}$. Kasyful Anwar. Beliau menggantikan KH. Hasan Ahmad menjadi pimpinan pesantren dari tahun 1922 hingga 1940. Pada periode itulah, sejumlah pembaruan dilakukan dalam rangka meningkatkan pendidikan pesantren. Aspek terpenting dari pembaruan tersebut adalah diperkenalkannya sistem klasikal/madrasah pada sistem pendidikan tradisional dengan sistem kelas berjenjang. Modernisasi PPD Martapura terus berlangsung sejalan dengan perkembangan masyarakat sekitar. Kebutuhan masyarakat sekitar terhadap pendidikan yang makin beragam-yang tidak hanya terbatas dibidang keagamaan—senantiasa memperoleh perhatian yang sangat besar dari pengelola pesantren. Oleh karena itu, saat ini PPD Martapura tidak hanya mendirikan lembaga

8 Lihat Pondok Pesantren Darussalam Martapura Kalimantan Selatan, Sejarah Singkat PP Darussalam Martapura http://www.pp-darussalam.com/2013/03/sejarah-singkatppdarussalam-martapura.html, diunggah pada 29 Maret 2013, diunduh pada 18 September 2014 pukul 14.15 wita 
pendidikan Islam kepesantrenan dan madrasah, tapi juga lembaga pendidikan umum. ${ }^{9}$

Adapun unit pendidikan yang diselenggarakan adalah Madrasah Diniyah (di daerah Martapura disebut madin) Tahdiriyah, madin Diniyah Awwaliyah, madin Wustha, madin Ulya, Madrasah Ibtidaiyah Darussalam, Sekolah Menengan Pertama Darussalam, Madrasah Aliyah Mu'alimin Darussalam, Sekolah Menengah Kejuruan Darussalam, Sekolah Tinggi Agama Islam Darussalam, Ma'had Tahfidz wa Ulumil Qur'an Darussalam, Ma'had Aly Darussalam, Takhasus Diniyah Darussalam, Program Kejar Paket A, B, dan C, Ukhuwah Ma'ahid Darussalam. ${ }^{10}$ Dari semua unit tersebut, unit madin yang paling diminati masyarakat. Hal itu terbukti dari santri yang berjumlah 9977 pada unit madin jauh lebih banyak dibanding pada unit lainnya yang berjumlah 2733 santri."

Berdasarkan unit-unit pendidikan, kurikulum, dan sistem pendidikan yang diselenggarakan PPD Martapura dapat dikatakan pesantren tersebut tidak dapat lagi disebut sebagai pesantren salafiyah atau tradisional murni. Pengkategorian sebagai pesantren kombinasi tampaknya lebih tepat, karena pendidikan dilaksanakan tidak hanya mengajarkan kitab kuning, tetapi pesantren membuka pendidikan formal dengan sistem klasikal. ${ }^{12}$ Selain itu, kurikulum yang dianut juga tidak hanya mengacu pada kurikulum Pondok Pesantren Darussalam sendiri, tetapi juga mengikuti kurikulum Kementerian Agama dan Kementerian Pendidikan.

Karena penelitian ini berfokus pada kekhasan pengajaran kitab kuning, unit yang dijadikan sebagai tempat memperoleh data utama adalah unit Madrasah Diniyah (madin). Madin dibatasi pada tingkat wustha dan ulya puteri karena keterbatasan peneliti untuk mengakses data disebabkan perbedaan gender antara peneliti dengan sumber data di madin putera. Selain itu,

9 Lihat Dokumen Pondok Pesantren Darussalam, Profil Pondok Pesantren Darussalam: Perkembangan Pesantren, h. 2-4

${ }^{10}$ PPD Martapura, Daftar Nama-nama Kitab. http://www. pp-darussalam.com/p/daftar-nama-kitab.html, dan Pondok Pesantren Darussalam Martapura, Profil Pondok Pesantren Darussalam, (Dokumen PPD: Martapura, tt), h. 7

"Dokumen Pondok Pesantren Darussalam, Daftar GuruGuru Pondok Pesantren Darussalam Seluruh Angkatan Tahun Ajaran 2013/2014; Daftar SantriPutera/Puteri.

12 Lihat Yasmadi, Modernisasi Pesantren: Kritik Nurcholis Madjid terhadap Pendidikan Islam Tradisional (Jakarta: Ciputat Press, 2002), h. 71 madin tingkat ulya masih menggunakan kitab sederhana yang dominan menggunakan kitab yang tidak berbahasa Arab. Adapun kurikulum, bidang studi, dan kitab referensi yang digunakan madin tingkat wushta dan ulya adalah sebagai berikut: ${ }^{13}$

\begin{tabular}{|c|c|c|c|c|}
\hline \multicolumn{5}{|c|}{ WUSTHO } \\
\hline \multicolumn{3}{|c|}{ اسماء الكتب } & \multirow{2}{*}{ الفن } & \multirow{2}{*}{ الهرق } \\
\hline 3 & 2 & 1 & & \\
\hline كتف الاسراير & هشى & كفائة العوالم & توحيد & 1 \\
\hline قتَح المعنين & قتي القريب & فنتح القريب & |نته & 2 \\
\hline شُرح ورقات & مذخل الوصول & رسلة اصول فته & اصول فته & 3 \\
\hline تروس التنسيز & كول المنير & عبم اصول تنسير & اصول تظسير & 4 \\
\hline تتوير الطلاب & تنزيرة الكنية & مثُن اليبقونية & اصول حليث & 5 \\
\hline نور الئينين & نور البقين & نور الئئن & تريغ & 6 \\
\hline كلة زبدة & النندة الحسنبة & تحفة السئرة & افرانض & 7 \\
\hline لغة التخاطب والرساتل & المداورة جزء 2 & المدورة جزء 1 & انثناء & 8 \\
\hline لامبة الافعل & الكيلانى & سلسل العذل & صرف & 9 \\
\hline الفية ابن ملك & كطر الثاى & المشسة & نحو & 10 \\
\hline ايضضاح العبهام & كول تول المعلق & فى على المنطق & منطق & 11 \\
\hline علم المعانى & توراع اللغنة العربية & $\cdot$ & بلاغة & 12 \\
\hline جلالين & جلالين & جلالين & تغسير & 13 \\
\hline بلوغ المرالم & رياض الصلعين & رياض الصاكين & حبيث & 14 \\
\hline رسلة المعاونة & تعليم المتَعلم & الثزبية والتهنيب & إخلاق & 15 \\
\hline
\end{tabular}

\section{ULYA}

\begin{tabular}{|c|c|c|c|c|}
\hline \multicolumn{3}{|c|}{ اعماء الكتب } & \multirow{2}{*}{ الفن } & \multirow{2}{*}{ الشرقم } \\
\hline 3 & 2 & 1 & & \\
\hline شرح الع اليراهين & تحفة الصريد & تحفة الصريد & توحيذ & 1 \\
\hline كقح الوهاب & فتّح الوهاب & اعاتة الطاليين & فتك & 2 \\
\hline اللمع & اللى & شرح قرة العين & اصول فثك & 3 \\
\hline كتاب التشهيل لعأو الثنزيل & انهو الثتيسر & الثناية & اصول تقعير & 4 \\
\hline لمنه نوى الثنظر & رفي الاستًار & طلعة الانوار & اصول حثبث & 5 \\
\hline تاريخ الذلناء. & تاريخ الذلفاء & محمث رسول الته & تريغ & 6 \\
\hline التنسورى & التشنسورى & شرحدرحبية & |فراتض & 7 \\
\hline علم التولفى & اشرث الوافى & مختصر الثافى & عروض & 8 \\
\hline المطلوب & ققَح الخبير اللطبين & شرح لامية الالفعال & صرت & 9 \\
\hline شرح اين عتيل & شرع ابن عتيل & شرح ابين عتيل & نحو & 10 \\
\hline شرع جومر المكنون & شرح جو مر المكون & شرح جوهر المكتون & منطق & 11 \\
\hline مشرح ايسا غوجى & التورسئى & شرح الاحضرى & بلاغة | بلاغ & 12 \\
\hline مراح اللبيد & مراح اللبين & جلالين & تغسير & 13 \\
\hline صحريح مسئ & صحتح مسلم & تجريد الصريح & حديث & 14 \\
\hline منهاج العابدين & كذاية الاتتياء & مراقى العببودية & اخلات & 15 \\
\hline
\end{tabular}

Kitab-kitab yang diajarkan di atas seluruhnya merupakan kitab tanpa harakat, kecuali kitab hadis yang matannya menggunakan harakat. Pada tingkat wustha dan ulya penguasaan santri pada ilmu nahwu atau ilmu alat terus dilatih dan dikembangkan. Penyebutan ilmu alat terhadap ilmu nahwu karena tata bahasa Arab ini dianggap sebagai alat untuk membaca dan menerjemahkan kitab kuning. Karenanya, dilihat dari gambar di atas dapat diketahui bahwa kitab nahwu dan saraf kajiannya semakin kompleks. Penguasaan ilmu alat selanjutnya diperdalam dengan mempelajari ilmu balaghah (tingkat wustha dan ulya) dan ilmu 'arudh (ulya). Selain itu diketahui pula bahwa sistem nilai yang

13 Lihat Pondok Pesantren Darussalam Martapura Kalimantan Selatan, Sejarah Singkat PP Darussalam Martapura, http://www.pp-darussalam.com/p/daftar-nama-kitab.html 
dianut dan diajarkan berpaham imam Syafi'i di bidang fikih, imam Asy'ari di bidang akidah, dan imam Ghazali di bidang akhlak. Dengan kata lain, pesantren tersebut menganut dan mengajarkan paham ahlussunah wa al-jamâ'ah (aswaja) kepada santriwati melalui kajian materi yang bersumber pada kitab-kitab kuning. Jadi, kitab-kitab mu'tabarah dijadikan sebagai sumber rujukan utama dalam pengajaran.

Dalam pengajaran kitab kuning guru membacakan, menerjemahkan, dan menjelaskan materi kitab kuning. Adapun aktivitas santri adalah mengharakati materi teks kitab kuning, mencatat terjemah atau arti kata, dan menyimak penjelasan guru. Karena tujuan pendidikan dan pengajaran adalah menghasilkan lulusan yang tafaqquh fî addîn melalui penguasaan kitab kuning, penekanan pada ilmu alat dan mufradât menjadi hal yang utama, seperti tampak pada kutipan pengajaran faraid kelas II A Wusta berikut:

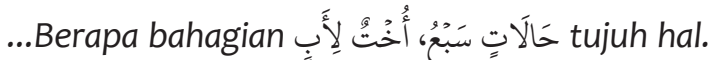

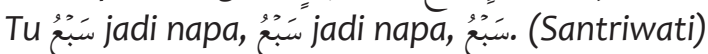
Khabar. (Guru) Khabar siapa, سَبُْعْ jadi khabar, khabarkah mubtadakah. (Santriwati) Mubtada. (Guru) han, baubah pulang, mana khabarnya. (Santriwati) Jumlah. (Guru) Jumlah siapa. (Santriwati) jumlah jar majrur. (Guru) jumlah

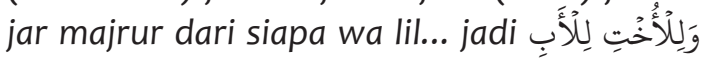
itu mubtada, apa khabar muqaddam, ya kah, سَالَاتِ سَبُْ mubtada muakhar, kaitu kah, bujur haja kah, bujur haja kah, iya, jadi jumlah jar majrur lah ngarannya tu, bujur haja kah,

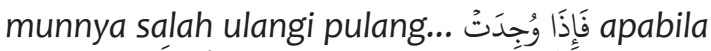

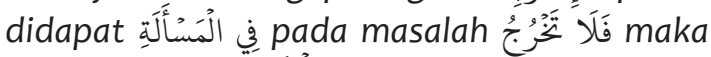

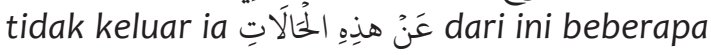
hal. Itu وُجََْ filil madhi napa. (Santriwati) Majhul. (Guru) Mana, mana, mana naibul fâ'ilnya, mana naibul fâ'ilnya, hajfun, mana

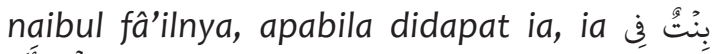
الَْسْأَلَّة pada masalah, baarti ada dhamir kah disitu. (Santriwati) Ada. (Guru) Dhamirnya napa. (Santriwati) Hiya. (Guru) dhamir hiya jadi napa inya. (Santriwati) Jadi naibul fầil. (Guru) Jadi, naibul fâ'il, bujur hajakah. (Santriwati) Bujur. (Guru) Pas hajakah. (Santriwati) Pas.

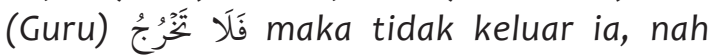
ditandar napa situ pulang, hiya pulang, hiya pulang lo. (Santriwati) lya. (Guru) هَنْ هَذِِ dari ini beberapa hal. Hal itu jamakkah mufradkah. (Santriwati) Jamak. (Guru) Jamak napa. (Santriwati) Jamak muannats. (Guru)

\section{Ha, jamak. (Santriwati) Muannats salim. ${ }^{14}$}

Berdasarkan kutipan di atas diketahui bahwa guru menerjemahkan teks materi perkata dan perfrasa. Meskipun pelajaran yang diajarkan adalah faraid, penekanan pada unsur ilmu alat tetap diterapkan. Dalam hal tersebut, selain membaca dan menterjemah guru menanyakan kedudukan kata dalam kalimat berdasarkan kaidah bahasa Arab dari teks materi kitab yang dibaca. Hal tersebut menegaskan bahwa gramatika bahasa Arab tidak hanya sekadar diajarkan pada pelajaran nahwu, saraf, atau balaghah saja, melainkan terintegrasi pada setiap pengajaran kitab kuning.Ini menegaskan pernyataan Haedari bahwa untuk mencapai tujuan tafaqquh fî ad-dîn santri harus mengembangkan keahlian dalam bahasa Arab, terutama ilmu alat seperti nahwu dan saraf guna menggali makna dan tafsir di balik teksteks yang terdapat pada kitab kuning. ${ }^{15}$

Penekanan penguaasaan ilmu alat juga merupakan orientasi yang ingin dicapai dalam pengajaran untuk menguasai kitab kuning. Jadi, pengetahuan tentang bahasa Arab bukan ditekankan untuk keterampilan berkomunikasi secara lisan, sebagaimana pernyataan pimpinan Pondok Pesantren Darussalam K.H. Khalilurrahman berikut.

(K.H. Khalilurrahman) Supaya kawa menguasai kitab ilmu alat yang utama diajarkan. Satu

${ }^{14}$ Kutipan transkrip pengajaran Faraid kelas II A Wusta. Kutipan di atas dialihbahasakan ke dalam bahasa Indonesia, yakni:

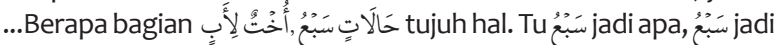

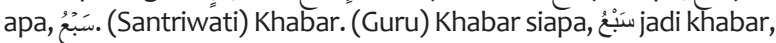
khabarkah mubtadakah. (Santriwati) Mubtada. (Guru) kan, berubah lagi, mana khabarnya. (Santriwati) Jumlah. (Guru) Jumlah siapa. (Santriwati) jumlah jar majrur. (Guru) jumlah jar majrur dari

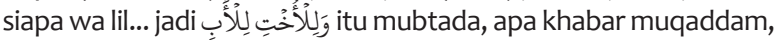
iya kan, حَالَالتِتَبُْ mubtada muakhar, begitukah, betulkah, betulkah, iya, jadi jumlah jar majrur ya namanya itu, betulkah, kalau salah

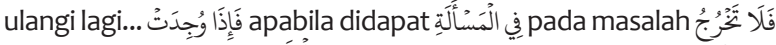

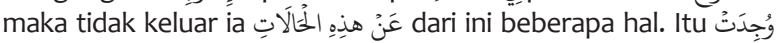
itu fi'il madli apa. (Santriwati) Majhul. (Guru) Mana, mana, mana naibul fa'ilnya, mana naibul fa'ilnya, hazfun, mana naibul fa'ilnya,

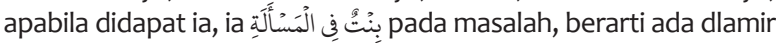
ya disitu. (Santriwati) Ada. (Guru) Dlamirnyaapa. (Santriwati) Hiya. (Guru) dlamirhiya jadi apa dia. (Santriwati) Jadi naibulfa'il. (Guru) Jadi, naibulfa'il, betulkah. (Santriwati) Betul. (Guru) Pas sajakan. (Santriwati) Pas. (Guru) فَلَ iَ digeser apa itu lagi, hiya lagi, hiya lagi kan. (Santriwati) lya. (Guru) dari ini beberapa hal. Hal itu apakah jamak apakah mufrad. (Santriwati) Jamak. (Guru) Jamak apa. (Santriwati) Jamak muannats. (Guru) Ha, jamak. (Santriwati) Muannatssalim.

15 HM. Amin Haedari, et.al. Transformasi Pesantren: Pengembangan Aspek Pendidikan, Keagamaan, dan Sosial, (Jakarta: Media Nusantara, 2006), h. 38. 
lagi, ilmu balaghah, ada lagi ilmu mantiq. Tu, semuanya tu termasuk ilmu alat dalam mempelajari kitab-kitab bahasa arab dan Qur'an serta Hadîs. (Peneliti) Inggih, jadi dasar utama untuk paham itu adalah ilmu alat muallim lah. (K.H. Khalilurrahman) IImu alat. ${ }^{16}$

Berdasarkan paparan data dan pernyataan di atas, kemampuan berbahasa Arab secara pasif lebih ditekankan dibanding dengan kemampuan aktif. Dengan kata lain, penguasaan bahasa Arab ditujukan untuk memahami dan menguasai kitab kuning. Karenanya, santriwati ketika berada di dalam pondok, baik di kelas maupun di asrama tidak menggunakan bahasa Arab sebagai alat komunikasi.

Penekankan penguasaan ilmu alat dan mufradât berimbas pada terjemahan yang dilakukan oleh guru dalam pengajaran kitab kuning. Terjemahan tersebut menggunakan sejumlah kata penanda untuk menunjukkan kedudukan kalimah (kata) dalam jumlah (kalimat) pada teks materi kitab kuning yang diajarkan. Kedudukan kata dalam kalimat pada bahasa Arab akan berpengaruh pada harakat akhir kata tersebut. Melalui terjemahan berkarakteristik khas kedudukan kata dalam kalimat dapat ditandai sesuai kaidah nahwu dan saraf. Ini dianggap sebagai cara yang dapat membantu santriwati dalam menguasai ilmu alat dan mufradât sekaligus memahami materi.Pada umumnya, terjemahan untuk menandakan kedudukan kalimah sebagai subjek (mubtada) adalah bermula, predikat (khabar) adalah yaitu adalah pelaku (fâ'il) adalah oleh, dan objek (maf"ûl) adalah akan. Adapun terjemahan untuk menandakan suatu kalimat plural (jamak) adalah berbilang-bilang, kata keterangan (min haitsu) adalah sekira-kira, dan keterangan keadaan (hal) adalah hal keadaan.

Teks materi kitab kuning diterjemahkan secara parsial sehingga terkategori sebagai terjemahan harfiah, karena terjemahan dilakukan kata demi kata yang bertujuan agar hasil terjemahan tidak

${ }^{16}$ Wawancara dengan K.H. Khalilurrahman, pimpinan Pondok Pesantren Darussalam (PPD), wawancara langsung dan semi terstruktur, di kantor pusat PPD. Kutipan di atas dialih bahasakan ke dalam bahasa Indonesia, yakni: (K.H. Khalilurrahman) Agar dapat menguasai kitab, ilmu alat yang utama diajarkan. Satu lagi, ilmu balaghah, ada lagi ilmu mantiq. Itu, semuanya itu termasuk ilmu alat dalam mempelajari kitab-kitab bahasa Arab dan Quran serta hadis. (Peneliti) lya, jadi dasar utama untuk paham itu adalah ilmu alat ya muallim. (K.H. Khalilurrahman) Ilmu alat. menyimpang sedikit pun dari ciri-ciri lahiriah bahasa sumber. ${ }^{17}$ Dengan kata lain, terjemahan yang menyesuaikan kaidah bahasa Arab sebagai bahasa sumber lebih diutamakan dibanding kaidah bahasa Indonesia sebagai bahasa target. Dalam hal ini, metode penerjemahan dapat dikategorikan sebagai metode penerjemahan setia (faithful translation). ${ }^{18}$ Meskipun demikian, terjemahan harfiah tersebut dapat dipahami oleh santriwati karena diberikan penjelasan oleh guru sebagai langkah untuk memantapkan pemahaman sekaligus mengantisipasi terjadinya kekeliruan pemahaman terhadap materi yang dipelajari.

Lebih detail dikatakan dalam Nababan bahwa pada dasarnya terjemahan kata per kata ini sangat terikat pada tataran kata. Dalam penerjemahan dicari padanan kata bahasa sumber dalam bahasa sasaran tanpa mengubah susunan kata dalam terjemahan. Susunan kata dalam kalimat terjemahan sama persis dengan struktur kalimat aslinya. Penerjemahan jenis ini dapat diterapkan hanya jika bahasa sumber dan bahasa sasaran mempunyai struktur yang sama. Jika struktur antara kedua bahasa tersebut berbeda, terjemahan akan sulit dipahami. ${ }^{19}$

Berdasarkan pernyataan Nababan di atas dapat dikatakan hal tersebutlah yang melatarbelakangi mengapa terjemahan berkarakteristik khas dalam pengajaran kitab kuning di PPD Martapura dapar bertahan. Terjemahan berkarakteristik khas tersebut jika ditelaah dari kaidah dan strukturnya sebenarnya adalah bahasa Melayu. Karena yang digunakan bahasa Melayu, terjemahan menjadi berkarakteristik khas, sebab berbeda dengan kaidah bahasa Indonesia sekarang yang lazim didengar, dibaca, dan ditulis oleh masyarakat secara umum. Bahasa Melayu digunakan oleh pengajar karena terdapat kesamaan antara kaidah bahasa tersebut dengan kaidah bahasa Arab. ${ }^{20}$ Adapun penggunaan bahasa Indonesia maupun

17 Lihat Peter Newmark, A Textbook of Translation (Newyork: Prentice Hall, 1988), h. 45dan Norlaila, Mampu Menerjemahkan: Teori Terjemahan Arab-Indonesia, (Yogyakarta: Kurnia Kalam Semesta, 2010), h. 41.

${ }_{18}$ Lihat Peter Newmark, A Textbook of Translation, (Newyork: Prentice Hall, 1988), h. 45.

${ }_{19}$ Lihat M. Rudolf Nababan, Teori Menerjemah Bahasa Inggris (Yogyakarta: Pustaka Pelajar, 2003), h. 30-33.

${ }_{20}$ Lihat Moch. Syarif Hidayatullah, "Bustan al Katibin: Pengaruh Tata Bahasa Arab dalam Tata Bahasa Melayu” dalam Jurnal Manassa: Manuskripta , (Vol. 2, No. 1, 2012, ISSN: 22525343), h. 73 
bahasa Banjar dalam terjemahan dihindari guru karena kaidah kedua bahasa tersebut berbeda dengan kaidah bahasa Arab.

Uraian tata bahasa Melayu dan struktur kalimatnya dapat dirujuk pada buku Bustân alKâtibîn dan, Kitab Pengetahuan Bahasa karya Raja Ali Haji. Pada dua karya tersebut begitu tampak keserupaan kaidah bahasa Melayu dengan kaidah bahasa Arab. ${ }^{21}$ Kemiripan kaidah kedua bahasa tersebut juga digambarkan oleh Moch. Syarif Hidayatullah yang menyatakan "Bustân alKâtibîn adalah buku pertama tata bahasa Melayu karya anak negeri yang dengan sangat gamblang memperlihatkan keterpengaruhan bahasa Melayu oleh bahasa Arab. Keterpengaruhan itu tidak hanya pada kosa kata, tetapi juga pada struktur dan kaidah tata bahasa."22

Pada buku tata bahasa Melayu karya Raja Ali Haji diuraikan di antara pembahasannya adalah pembagian kelas kata seperti kutipan berikut:

Kelas kata dalam bahasa Melayu terdiri atas ism (kata benda), fi'il (kata kerja), dan harf (partikel) serta pilahan-pilahannya.... Ism terbagi dua, yaitu ism nakirah...(nomina tak takrif) dan ism ma'rifah...(nomina takrif) yang terdiri atas ism dhamir... ism 'alam... ism isyarah... ism maushûl... ism idhafah.... Fi'il madli...ditandai oleh kata telah, fi'il mudhari'...ditandai oleh kata lagi akan, fi'il amr...yakni menyuruh berbuat.... fi'il lazim...(verba intransitif)...dan fi'il muta'addi (verba transitif).... Harf-harf itu adalah harf munada... harf li at-tahqiq... harf bertanya... harf menjawab... harf 'ataf.... Analisis kalimat... mubtada (pokok atau subjek) dan khabar (sebutan atau predikat)...maf'ûl (objek)... hal (determinator), tamyiz (spesifikasi), badl (permutatif), shifah (adjektif), idhafah (frasa nominal-posesif). ${ }^{23}$

${ }^{21}$ Kesamaan antara kaidah bahasa Melayu dengan kaidah bahasa Arab dijelaskan oleh Harimurti Kridalaksana dalam Bustanul Katibin dan Kitab Pengetahuan Bahasa: Sumbangan Raja Ali Haji dalam Bahasa Melayu, Artikel ditulis dalam rangka peringatan Hari Sastra 83 dengan tema "Tradisi Johor-Riau di Alam Melayu" yang diselenggarakan oleh Gabungan Persatuan Penulis Nasional Malaysia, Johor Baru, Malaysia 10-13 Desember 1983, h. 13, dan Pendekatan Historis dalam Kajian Bahasa Melayu dan Indonesia, artikel disampaikan pada forum Dewan Bahasa dan Pustaka Kuala Lumpur 14 April 1984, h. 54

${ }^{22}$ Moch. Syarif Hidayatullah, "Bustan al Katibin: Pengaruh Tata Bahasa Arab dalam Tata Bahasa Melayu" dalam Jurnal Manassa: Manuskripta (Vol. 2, No. 1, 2012, ISSN: 2252-5343), h. 53.

${ }^{23}$ Lihat Harimurti Kridalaksana dalam Bustanul Katibin dan Kitab Pengetahuan Bahasa: Sumbangan Raja Ali Haji dalam
Berdasarkan kutipan di atas dapat dilihat kaidah bahasa Arab digunakan oleh Raja Ali Haji selaku penulis pertama tata bahasa Melayu asal Indonesia untuk mengurai tata bahasa Melayu. ${ }^{24}$ Dengan kata lain, terdapat keserupaan antara kaidah bahasa Arab dan bahasa Melayu, sehingga terjemahan berkarakteristik khas dalam pengajaran kitab kuning dapat diterapkan dan tetap bertahan.

Adapun argumentasi mengapa terjemahan berkarakteristik khas dalam pengajaran kitab kuning tetap dipertahankan oleh guru secara lebih bermakna dapat ditelisik dari sudut pandang sosiolinguistik.

Bahasa Melayu, Artikel ditulis dalam rangka peringatan Hari Sastra 83 dengan tema "Tradisi Johor-Riau di Alam Melayu" yang diselenggarakan oleh Gabungan Persatuan Penulis Nasional Malaysia, Johor Baru, Malaysia 10-13 Desember 1983, h. 10-12. Selengkapnya untuk melihat analisis kalimat bahasa Melayu yang juga diurai dengan tata bahasa Arab dapat dilihat pada h. 12-13

${ }^{24}$ Sebelum buku Bustân al-Kâtibîn ditulis dengan huruf Arab oleh Raja Ali Haji sekitar 1857 M. bahasa Melayu pada abad ke-17 telah mendominasi arena budaya di seluruh daerah Asia tenggara. Bahasa Melayu bernuansa Islam tersebar di manuskrip-manuskrip bertuliskan Jawi. Namun, bahasa Melayu relatif mapan baru terjadi pada abad ke-19. Kemapanan tersebut ditandai dengan ditulisnya buku tata bahasa Melayu dan kamus bahasa Melayu oleh linguis dari Eropa yang ditujukan untuk dipelajari dan dipergunakan bagi kepentingan kolonialisme dan misionarisme. Buku tersebut ditulis sesuai standar kaidah bahasa Eropa. Meskipun demikian, pada abad ke-19 tersebut Raja Ali Haji sebagai orang Indonesia pertama dan ahli bahasa juga turut berkontribusi dalam pembakuan bahasa Melayu melalui karyanya Bustân al-Kâtibîn li ash-Sibyân al-Muta'allimîn. Bahkan, buku tersebut merupakan buku tata bahasa Melayu pertama yang ditulis oleh orang Melayu sendiri. Buku tersebut dipelajari di sekolah-sekolah kerajaan Riau guna mempelajari bahasa Arab dan teks keagamaan Islam. Dalam hal ini, Raja Ali Haji bahkan dinyatakan telah 'memerdekakan' bahasa Melayu dari pengaruh bahasa Belanda. Harimurti Kridalaksana dalam Moch. Syarif Hidayatullah mengapresiasi Bustân al-Kâtibîn dengan mengatakan buku tersebut telah menunjukkan bahwa gramatika bahasa Arab pernah memengaruhi dunia bahasa dan dunia pengajaran bahasa Indonesia. Digunakannya aksara Arab dan kaidah bahasa Arab dalam menguraikan kaidah bahasa Melayu dikatakan oleh Harimurti Kridalaksana karena Raja Ali Haji ingin mengkontraskan tata bahasa yang dibuatnya dengan tata bahasa Melayu versi orang Belanda. Di samping itu, bahasa Arab merupakan simbol agama Islam, agamanya orang Melayu kebanyakan. Hal tersebut juga didukung oleh kenyataan bahwa hampir di setiap kasus bahasa Melayu memiliki kesesuaian dengan kasus bahasa Arab (kecuali kasus pada isim majrur). Selain itu, bahasa Arab juga dipilih atas pertimbangan akses keilmuan yang dimiliki oleh Raja Ali Haji. Hal ini tidak terlepas dari konteks zaman pada waktu tersebut, dimana tradisi pemikiran didominasi oleh buku-buku berbahasa Arab sebagai hasil dari perkembangan agama Islam. Kondisi tersebut turut memengaruhi Raja Ali Haji dan masyarakat pada masa itu dalam menulis, membaca, dan mengekspresikan gagasan. Lihat Moch. Syarif Hidayatullah, "Bustan al Katibin: Pengaruh Tata Bahasa Arab dalam Tata Bahasa Melayu" dalam Jurnal Manassa: Manuskripta (Vol. 2, No. 1, 2012, ISSN: 2252-5343), h. 54-72 
Pada ranah ini, pilihan dan penggunaan kode (bahasa, dialek) oleh penutur dalam peristiwa tutur setidaknya banyak dipengaruhi oleh topik (kajian kitab kuning), partisipan (santriwati), dan tempat (pesantren dengan lingkungan yang berpaham aswaja dan mengutamakan penguasaan ilmu alat dan mufradât). Pilihan kode tersebut akan berpengaruh pada kedudukan penutur dalam masyarakat tutur. Dalam hal ini, motif pilihan kode ditujukan untuk menentukan kedudukan penutur dalam masyarakat tutur.

Pada PPD Martapura tujuan pendidikan dan pengajaran adalah santriwati memahami dan menguasai ajaran agama Islam dengan paham aswaja melalui sumber rujukan kitab kuning. Alat utama untuk mencapai tujuan tersebut adalah dengan menguasai ilmu alat dan mufradât. Penguasaan kedua unsur tersebut ditunjukkan melalui kemampuan membaca teks materi sesuai kaidah bahasa Arab dan kemampuan menerjemahkannya. Terjemahan berkarakteristik khas dianggap sebagai indikator penguasaan seseorang terhadap ilmu alat dan mufradât. Hal tersebut berlaku karena terjemahan berkarakteristik khas (bahasa Melayu) justru mengacu dan mengutamakan kaidah bahasa sumber (bahasa Arab) dibanding bahasa sasaran (bahasa Indonesia). Karenanya, melalui terjemahan berkarakteristik khas (bahasa Melayu) menunjukkan bahwa penuturnya menguasai kaidah bahasa Arab dan mufradât.

Karena menguasai kaidah bahasa Arab dan mufradât, seseorang di lingkungan pesantren mendapatkan prestise. Prestise tersebut diperoleh dari lingkungan pesantren karena seseorang tersebut dianggap berpotensi menguasai ilmu agama Islam melalui penguasaannya pada ilmu alat dan mufradât yang ditunjukkan dengan terjemahan berkarakteristik khas. Terkait dengan hal ini, Madjid menyatakan bahwa penguasaan dalam bidang ilmu alat akan mengantarkan seseorang memperoleh status sosial keagaamaan karena salah satu syarat untuk mendapatkan gelar ustaz atau kiai telah terpenuhi. Konotasi keagamaan dalam keahlian di bidang ini adalah karena sumber rujukan utama ajaran Islam berbahasa Arab. ${ }^{25}$ Dengan kata lain, seseorang dengan penguasaan tersebut dianggap

${ }^{25}$ Nurcholis Madjid, Bilik-bilik Pesantren: Sebuah Potret Perjalanan, (Jakarta: Paramadina, 1997), h. 8. berhasil mencapai indikator tujuan pendidikan dan pengajaran di pesantren.

Berdasarkan uraian di atas, dapat dikatakan bahwa penguasaan kaidah bahasa Arab dan mufradât tercermin dari terjemahan berkarakteristik khas atau terwakili pada bahasa Melayu. Dalam hal ini, kedudukan bahasa Melayu (terjemahan berkarakteristik khas) pada lingkungan pesantren lebih tinggi dan lebih prestisius dibanding bahasa Indonesia dan bahasa Banjar.

Bahasa Melayu dianggap sebagai ragam tinggi dan prestisius karena melalui bahasa tersebut akan menunjukkan penuturnya menguasai ilmu alat dan mufradât sebagai sarana utama untuk memahami kitab kuning guna menguasai ajaran agama Islam. Dalam hal ini, bahasa Melayu memiliki peranan penting di dalam masyarakat pesantren.

Selain itu, pola atau kaidah bahasa Melayu dapat membantu santriwati memahami kaidah bahasa Arab sekaligus menandai arti kata di tiap kata dalam kalimat dari teks yang diajarkan. Karenanya, bahasa Melayu dipandang sebagai bahasa yang indah dan bagus dalam konteks pengajaran kitab kuning menjadi hal yang tidak dapat dinafikan. Terkait dengan hal tersebut Ferguson menyatakan "...there is usually a belief that high is somehow more beautiful, more logical, better able to express important thoughts, and the like". ${ }^{26}$ Pernyataan tersebut menegaskan bahwa pretise suatu bahasa berkaitan dengan sikap penutur yang menganggap bahasa tinggi adalah bahasa yang dapat mengekspresikan pikiran. Bahasa Melayu dianggap dapat melakukan hal tersebut karena kaidahnya lebih dapat mencerminkan kaidah bahasa Arab dibanding gramatika bahasa Indonesia atau pun bahasa Banjar.

Berdasarkan uraian kajian di atas dari bahasan ragam bahasa tinggi dan ragam bahasa rendah dapat dianalisis mengapa terjemahan berkaraktersitik khas tetap dipertahankan oleh guru maupun masyarakat pesantren hingga sekarang. Selain dapat ditelaah dari ragam bahasa, pemertahanan terjemahan berkarakteristik khas juga dapat dianalisis dari kelas sosial.

Guru selain sebagai pengajar juga dipandang

${ }^{26}$ Charles Ferguson, "Diglossia" dalam Christina Bratt Paultson and G. Richard Tucker (eds.) Sociolinguistics: the Essential Readings (USA: Blackwell Publishing, 2003), h. 348. 
sebagai orang yang menguasai ilmu agama Islam dan dianggap sebagai orang yang saleh serta berwibawa. Hal ini sebagaimana dinyatakan oleh Suardi bahwa kiai, (termasuk guru) adalah orang yang ahli dalam ilmu agama yang memiliki kualifikasi kesalehan melalui pengabdian secara total terhadap tugas-tugas yang diemban dan kualifikasi akademik yang ditunjukkan dengan penguasaannya dalam disiplin ilmu agama (kitab kuning). ${ }^{27}$ Dengan kata lain, seorang kiai akan disebut alim oleh masyarakat manakala ia memahami dan mengamalkan ajaran Islam, termasuk mengajarkan kitab kuning. ${ }^{28}$ Dalam hal ini, guru dihormati dan disegani, bahkan dijadikan sebagai teladan dalam berperilaku pada masyarakat pesantren. Dengan demikian, guru memiliki kedudukan yang prestisius, sehingga mereka dijadikan sebagai publik figur atau model dalam berperilaku, termasuk dalam tuturan yang digunakannya dalam pengajaran kitab kuning. Dalam hal ini, Bloomfield menyatakan:

... a speaker will imitate those whom he believes to have the highest "social" standing. To take the extreme case, when a speaker comes in contact with persons who enjoy much greater prestige, he eagerly imitates not only their general conduct, but also their speech. Here the direction of leveling is most plainly apparent. The humble person is not imitated; the lord or leader is a model to most of those who hear him. ${ }^{29}$

Kutipan di atas juga berlaku di PPD Martapura, karena guru memiliki kedudukan prestisius, tuturan mereka diikuti oleh santriwati. Selain diikuti oleh santriwati, alumni pesantren tersebut pun ketika menjadi pengajar di pesantren setempat atau di pesantren lain yang mengutamakan kajian kitab kuning, bahasa yang digunakan dalam menerjemahkan teks materi kitab kuning adalah bahasa yang melambangkan status prestise, yakni bahasa Melayu sebagaimana yang dilakukan oleh guru mereka sebelumnya.

Berdasarkan uraian analisis di atas, diketahui

27 Lihat Imron Arifin, Kepemimpinan Kiai: Kasus Pondok Pesantren Tebu Ireng, (Malang: Kalimasahada Press, 1993), h. 49.

${ }^{28}$ Lihat Suardi, Pesantren dan Kitab Kuning: Sejarah, Metode, dan Paham, dalam Samsul Nizar, et. al, Sejarah Sosial dan Dinamika Intelektual Pendidikan Islam di Nusantara, (Jakarta: Kencana Prenada Media Group, 2013), h. 148.

${ }^{29}$ Leonard Bloomfield, Language, (New York: Henry Holt, 1933), h. 476 bahwa ragam bahasa (bahasa Melayu sebagai ragam bahasa tinggi dalam pengajaran kitab kuning, khususnya dalam menerjemahkan teks materi) dan kelas sosial (guru yang memiliki kedudukan prestisius menggunakan bahasa Melayu dalam menerjemahkan teks materi kitab kuning) dapat memengaruhi sikap positif penutur (santriwati) terhadap bahasa Melayu. Keadaan tersebut di atas semakin mempertegas argumen mengapa terjemahan berkarakteristik khas dalam pengajaran kitab kuning dapat terus dan tetap dipertahankan.

\section{Penutup}

PPD Martapura meskipun telah banyak bersentuhan dan mengadopsi modernitas dalam sistem pendidikan, pengajaran kitab kuning tetap menjadi karakteristik utama dari pesantren tersebut. Dalam pengajaran kitab kuning terdapat keunikan di dalamnya. Keunikan tersebut tampak pada terjemahan berkarakteritik khas yang diterapkan guru sebagai dampak dari penekanan penguasaan ilmu alat dan mufradât sebagai alat utama untuk memahami kitab kuning guna menguasai ajaran agama Islam. Terjemahan yang diterapkan menggunakan sejumlah kata penanda untuk menunjukkan kedudukan kata dalam kalimat. Selain itu, terjemahan yang diproduksi secara lisan oleh guru juga lebih mengutamakan kaidah bahasa Arab dibanding bahasa Indonesia, sehingga terjemahan tampak kaku dan janggal. Meskipun demikian, kondisi ini tetap dan dapat dipertahankan. Fenomena unik ini dapat dipahami dengan menelaahnya pada aspek linguistik dan sosiolinguistik.

Terjemahan berkarakteristik khas (karena dilakukan secara harfiah dan menggunakan kata penanda) dilihat dari strukturnya merupakan bahasa Melayu. Struktur dan tata bahasa Melayu memiliki kemiripan dengan struktur dan kaidah bahasa Arab. Keserupaan inilah yang membuat terjemahan berkarakteristik khas (bahasa Melayu) dalam pengajaran kitab kuning dapat diterapkan dan bertahan.

Berdasarkan aspek sosiolinguistik bahasa Melayu dianggap sebagai ragam bahasa tinggi dan prestisius dalam pengajaran kitab kuning khususnya dalam menerjemahkan teks materi, karena menunjukkan penguasaan ilmu alat dan mufradât bagi penuturnya. Pada telaah kelas 
sosial, guru memiliki kedudukan yang prestisiusdan dijadikan sebagai model atau publik figur, sehingga tuturan mereka yang menggunakan bahasa Melayu dalam menerjemahkan teks materi kitab kuning diikuti oleh santriwati. Bahasa Melayu sebagai ragam bahasa tinggi dan digunakan oleh publik figur dalam pengajaran kitab kuning memengaruhi sikap positif santriwati terhadap bahasa tersebut. Keadaan inilah yang menyebabkan terjemahan berkarakteristik khas dipertahankan dalam pengajaran kitab kuning.

\section{Pustaka Acuan}

Arifin, Imron, Kepemimpinan Kiai: Kasus Pondok Pesantren Tebu Ireng. Malang: Kalimasahada Press, 1993.

Bloomfield, Leonard, Language.New York: Henry Holt, 1933.

Bruinessen, Martin van, Kitab Kuning, Pesantren danTarekat. Edisi revisi. terj. Farid Wajidi, et.al, Yogyakarta: Gading Publishing, 2012.

Dhofier,Zamakhsyari, Tradisi Pesantren: Studi Tentang Pandangan Hidup Kiai, Jakarta: LP3ES, 1982.

Dokumen Pondok Pesantren Darussalam Martapura Kalimantan Selatan, PPD Martapura, t.t.

Dokumen Pondok Pesantren Darussalam, Daftar Guru-Guru Pondok Pesantren Darussalam Seluruh Angkatan Tahun Ajaran 2013/2014; Daftar Guru Tingkat Ulya Putera/Puteri dan Daftar Guru Tingkat Wusta Puteri.

Faiqoh, "Pengajaran Kitab Kuning di Pondok Pesantren Cidahu Pandeglang", Mimbar 28, No. 2, 2012.

Ferguson, Charles, "Diglossia" in Sociolinguistics: the Essential Readings, eds. Christina Bratt Paultson and G. Richard Tucker. USA: Blackwell Publishing, 2003.

Haedari, H.M. Amin, Transformasi Pesantren: Pengembangan Aspek Pendidikan, Keagamaan, dan Sosial. Jakarta: Media Nusantara, 2006.

Hidayatullah, Moch. Syarif, "Bustan al Katibin: Pengaruh Tata Bahasa Arab dalam Tata Bahasa Melayu" dalam Jurnal Manassa: Manuskripta, Vol. 2, No. 1, 2012.

Kridalaksana, Harimurti, Bustanul katibin dan Kitab Pengetahuan Bahasa: Sumbangan Raja Ali Haji dalam Bahasa Melayu, Artikel ditulis dalam rangka peringatan Hari Sastra 83 dengan tema
“Tradisi Johor-Riau di Alam Melayu” yang diselenggarakan oleh Gabungan Persatuan Penulis Nasional Malaysia, Johor Baru, Malaysia 10-13 Desember 1983

, Pendekatan Historis dalam Kajian Bahasa Melayu dan Indonesia, artikel disampaikan pada forum Dewan Bahasa dan Pustaka Kuala Lumpur 14 April 1984.

Madjid, Nurcholis, Bilik-bilik Pesantren: Sebuah Potret Perjalanan, Jakarta: Paramadina, 1997. Muhammad, Abu Abdillah bin Daud as-Shanhaj bin al-Jurum,. al Matn al-Ajrumiyah, Surabaya: Bongkol Indah, t.t.

Nababan, M. Rudolf, Teori Menerjemah Bahasa Inggris, Yogyakarta: Pustaka Pelajar, 2003.

Newmark, Peter, A Textbook of Translation, Newyork: Prentice Hall, 1988.

Norlaila, Mampu Menerjemahkan: Teori Terjemahan Arab-Indonesia, Yogyakarta: Kurnia Kalam Semesta, 2010.

Pondok Pesantren Darussalam Martapura Kalimantan Selatan, Sejarah Singkat PP Darussalam Martapura, http://www.pp-darussalam.com/p/ daftar-nama-kitab.html, 18 Oktober 2014

Pondok Pesantren Darussalam Martapura, Profil Pondok Pesantren Darussalam, Dokumen PPD: Martapura, tt.

Pondok Pesantren Darussalam Martapura Kalimantan Selatan, Sejarah Singkat PP Darussalam Martapura, http://www.pp-darussalam.com/p/ daftar-nama-kitab.html.

PPD Martapura, Daftar Nama-nama Kitab. http:// www.pp-darussalam.com/p/daftar-nama-kitab. html

Sa'adah, Mazro’atus, “Pengaruh Doktrin Tertutupnya Pintu ljtihad Terhadap Pola Pengajaran Hukum Islam di Pondok Pesantren Tradisional", Jurnal At-Tajdid, Vol 1, No.1, 2012.

Suardi, "Pesantren dan Kitab Kuning: Sejarah, Metode, dan Paham", dalam Sejarah Sosial dan Dinamika Intelektual Pendidikan Islam di Nusantara, eds. Samsul Nizar, et al, Jakarta: Kencana Prenada Media Group, 2013.

Yasin, A. Fatah, Dimensi-dimensi Pendidikan Islam, Malang: UIN-Malang Press, 2008.

Yasmadi, Modernisasi Pesantren: Kritik Nurcholis Madjid Terhadap Pendidikan Islam Tradisional, edisi revisi, Ciputat: Quantum Teaching, 2002. 